\title{
EFFECTS OF INTRANASAL BACTERIAL ENDOTOXIN ADMINISTRATION ON EXPRESSION OF ALPHA-SYNUCLEIN IN PERIPHERAL STRUCTURES OF THE OLFACTORY SYSTEM
}

\author{
T.N. Sergeyeva, K.S. Sergeyeva
}

Udmurt State University, Izhevsk, Russia

\section{ВЛИЯНИЕ ИНТРАНАЗАЛЬНОГО ВВЕДЕНИЯ БАКТЕРИАЛЬНОГО ЭНДОТОКСИНА НА ЭКСПРЕССИЮ АЛЬФА-СИНУКЛЕИНА В ПЕРИФЕРИЧЕСКИХ СТРУКТУРАХ ОЛЬФАКТОРНОЙ СИСТЕМЫ}

\author{
Т.Н. Сергеева, К.С. Сергеева
}

ФГБОУ ВО «Удмуртский государственный университет», Ижевск

The involvement of olfactory dysfunction led to the proposal of 'the olfactory vector hypothesis' to explain both olfactory losses and the etiology of idiopathic Parkinson disease (PD) as a result of the transit of an environmental virus or chemical agent that enters the central nervous system (CNS) via the nose, activating the glial response of the brain that may lead to dopamine neuronal damage. Previously created chronic, progressive a mouse model of PD by intranasal instillation of a LPS displayed several key features of early-stage PD: a progressive hypokinesia, selective loss of dopamine neurons, a reduction in striatal dopamine content, and $\alpha$-synuclein ( $\alpha$-syn) accumulation and aggregation in the substance nigra. Other PD model based on nasal inoculation with $\alpha$-syn aggregates also expressed parkinsonian-like behavioral and immunological features.

We suggested that intranasal administration of LPS might cause an increase in expression and misfolding of $\alpha$-syn in olfactory receptor cells that are projected into olfactory bulbs. We observed an increase in the expression of the native and phosphorylated forms of immunoreactive $\alpha$-syn in olfactory cells, olfactory nerve and olfactory bulbs where, in addition, activated glial cells were observed. The findings suggest that bacterial antigens can cause parkinsonian-like features both by inducing a glial neuroinflammatory response and by increasing the production of phosphorylated $\alpha$-syn in peripheral structures of the olfactory system.

Keywords: lipopolysaccharide; Parkinson's disease; $\alpha$-synuclein; olfactory neurons.

Обонятельная дисфункция при идиопатической болезни Паркинсона (БП) позволила предположить так называемую «гипотезу обонятельного вектора», утверждающую, что БП возникает в результате переноса вируса или химического агента в ЦНС через обонятельные пути, что ведет к активации глиальных клеток и последующему повреждению дофаминовых нейронов.

Ранее разработанная модель хронической прогрессирующей БП у мышей с интраназальным введением липополисахарида (ЛПС) продемонстрировала несколько ключевых особенностей ранней стадии БП: прогрессирующую гипокинезию, избирательную потерю дофаминовых нейронов, снижение содержания дофамина в полосатом теле и накопление и агрегацию $\alpha$-синуклеина $(\alpha$-syn) в черной субстанции головного мозга. Другая модель БП на основе назальной инокуляции агрегатами $\alpha$-syn также демонстрировала паркинсоноподобные поведенческие и иммунологические особенности. Мы предполагаем, что интраназальное введение ЛПС приводит к увеличению экспрессии и неправильному фолдингу $\alpha$-syn в обонятельных рецепторных клетках, проецируемых в обонятельные луковицы. Нами продемонстрировано увеличение экспрессии нативной и фосфорилированной форм иммунореактивного $\alpha$-syn в обонятельных луковицах, где также наблюдались активированные глиальные клетки. Полученные результаты позволяют сделать вывод, что бактериальные антигены могут вызывать признаки, соответствующие паркинсонизму, вызывая глиальный нейровоспалительный ответ, а также путем увеличения продукции фосфорилированного $\alpha$-syn в периферических структурах обонятельной системы.

Ключевые слова: липополисахарид; болезнь Паркинсона; $\alpha$-синуклеин; обонятельные нейроны. 